\title{
Penerapan Strategi Giving Question And Getting Answer Sebagai Upaya Peningkatkan Hasil Belajar Akuntansi
}

\author{
Sulaiman Effendi \\ Syarifah Ainah Siregar \\ Fakultas Keguruan Dan Ilmu Pendidikan Universitas Muhammadiyah Sumatera Utara \\ Jl. Mukhtar Basri No. 3 Medan Indonesia \\ Coresponden; sulaiman_usm@yahoo.com
}

\begin{abstract}
ABSTRAK
Penelitian ini bertujuan untuk meningkatkan hasil belajar akuntansi siswa dengan penerapan strategi pembelajaran Giving Question and Getting Answer pada pokok bahasan Jurnal Umum dikelas X SMK Ar-Rahman Medan T.P 2016/2017. Metode penelitian menggunakan penelitian tindakan kelas dengan sampel berjumlah 38 orang siswa. Instrumen penelitian ini adalah tes dan observasi tehnik analisis data deskriptif. Berdasarkan hasil analisis data bahwa hasil belajar pada siklus I diperoleh sebanyak 20 siswa $(52,63 \%)$ yang mencapai KKM dan yang belum mencapai KKM 18 siswa (47,37\%). Sedangkan untuk hasil belajar untuk siklus II diperoleh sebanyak 33 siswa $(88,84 \%$ ) yang mencapai KKM dan yang belum mencapai KKM sebanyak 5 siswa $(13,16 \%$ ). Berdasarkan hasil siklus II diketahui bahwa hasil belajar siswa telah meningkat sebesar 34,21\% artinya bahwa penerapan strategi Giving Question and Getting Answer dapat meningkatkan hasil belajar siswa akuntansi
\end{abstract}

Kata kunci : Penerapan Strategi Giving Question and Getting Answer

\section{ABSTRACT}

This research aims to improve the learning results of accounting students with the application of learning strategies Giving Question and Getting the Answer on the subject of general Journal in class X SMK Ar Rahman - Medan T.P. 2016/2017. Research methods using the class action research with the sample amounted to 38 students. Research instrument this is a test and observation techniques descriptive data analysis. Based on the results of data analysis that the results of the study on cycle I gained a total of 11 students $(28.94 \%)$ to reach the KKM and who has not yet reached the KKM 27 students (71.05\%). As for the results of the study for cycle II retrieved as many as 32 students (84.21\%) to reach the KKM and who has not yet reached the KKM sis wa (15.78\%). Based on the results of cycle II note that student learning outcomes has increased by $55.27 \%$ it means that the application of the strategy of Giving Question and Getting Answer can improve student learning accounting results

Keyword: application of a strategy Giving Question and Getting Answer

\section{PENDAHULUAN}

Pada era globalisasi pendidikan

kualitas sumber daya manusia salah memiliki peran penting karena pendidikan merupakan wadah untuk meningkatkan dan mengembangkan satu cara yang dilakukan untuk meningkatkan mutu dan kualitas pendidikan adalah dengan cara 
pembeharuan sistem pendidikan. Pendidikan yang dimaksud disini adalah siswa yang dituntut aktif dalam pembelajaran atau pembelajaran berpusat pada siswa (student centre) dan sebaliknya bukan guru yang memberikan pengetahuan kepada siswa (teacher centre) atau sumber satusatunya untuk belajar karena guru hanya sebagai fasilitator dan motivator untuk mencapai tujuan pendidikan.

Dalam dunia pendidikan, peran seorang guru sangatlah penting karena menjadi pengajar sekaligus pendidik bagi muridnya. Mengajar merupakan suatu hal yang sangat rumit bagi seorang guru. Guru bukan hanya mengajar bahkan harus menentukan strategi mana yang harus sesuai dengan materi pembelajaran. Dalam proses belajar mengajar strategi mempunyai peranan yang sangat penting karena setiap guru yang mengajar didalam suatu kelas memilih strategi yang tepat untuk semua materi yang akan disampaikannya, agar proses pembelajaran berjalan dengan lancer dan memiliki hasil yang optimal dan suasana kelas menjadi menyenangkan dan siswa mudah menyerap apa yang disampaikan oleh gurunya.

Kejenuhan siswa merupakan hal yang sangat penting karena berpengaruh terhadap hasil belajar siswa. Siswa cenderung malas mendengarkan apa yang disampaikan karena proses pembelajaran yang kurang menarik sehingga siswa mudah bosan, mengantuk bahkan kabur pada materi pembelajaran tersebut karena guru yang hanya terfokus terhadap materi yang disampaikan. Akuntansi merupakan salah satu bagian dari cabang ilmu sosial yang cukup unik karena didalamnya dipelajari seni dalam pencatatan keuangan. Akuntansi sering dianggap sebagai sesuatu yang sulit, rumit dan membosankan bagi siswa. Hal ini biasa terjadi pada siswa kelas X yang baru mengenal akuntansi.

Berhasil atau tidaknya suatu pendidikan sangat dipengaruhi oleh pembelajaran yang berlangsung. Pembelajaran adalah suatu proses yang rumit karena tidak sekedar menyerap informasi dari guru tetapi melibatkan berbagai kegiatan dan tindakan yang harus dilakukan untuk meningkatkan hasil belajar yang lebih baik. Berdasarkam hasil wawancara yang dilakukan penulis pada tanggal 15 Desember 2017 dengan guru akuntansi Ibu Erlina Wati guru bidang studi akuntansi yang dilaksanakan di SMK AR- RAHMAN MEDAN, bahwa hasil belajar akuntansi tergolong masih rendah.

Hal ini dapat dilihat dari hasil ujian tengah semester yang diperoleh siswa rata- rata 60 dengan jumlah siswa 38 orang hanya 8 orang yang memiliki nilai tuntas dan yang lainnya 30 orang dinyatakan tidak tuntas, padahal nilai KKM yang ditentukan sekolah tersebut untuk mata pelajaran akuntansi adalah 75. Tabel dibawah ini menunjukkan hasil belajar siswa sebagai berikut: 
Tabel 1.1

Daftar Nilai Harian Siswa Kelas X SMK AR- RAHMAN MEDAN T.P 2016/2017

\begin{tabular}{|c|c|c|c|}
\hline No & Jumlah Siswa & Nilai & $\%$ \\
\hline 1 & $\mathbf{8}$ orang & $\geq 75$ & $4.75 \%$ \\
\hline 2 & 30 orang & $<75$ & $\mathbf{9 5 . 2 5 \%}$ \\
\hline Jumlah & 38 orang & - & $100 \%$ \\
\hline
\end{tabular}

Sumber : guru bidang studi Akuntansi kelas X SMK Ar- Rahman Medan

Dari tabel diatas dapat dilihat bahwa masih banyak siswa yang hasil belajar akuntansinya masih dibawah KKM yang ditetapkan sekolah. Hal ini menunjukkan bahwa hasil belajar Akuntansi masih perlu ditingkatkan. Rendahnya hasil belajar siswa dapat berasal dari siswa, guru, motivasi yang rendah, sarana prasarana yang kurang memadai, siswa kurang aktif dalam proses pembelajaran, serta kurang bervariasinya metode pembelajaran yang digunakan guru. Dimana peranan guru sangat dominan dan tidak memberikan akses bagi siswa untuk berkembang secara mandiri sehingga siswa menjadi bosan, kurang berminat dalam belajar dan tidak dapat menyerap materi pembelajaran dengan baik. Proses pembelajaran tersusun atas sejumlah komponen atau unsur yang saling berkaitan dan saling berinteraksi satu sama lain. Intraksi guru dan siswa saat proses pembelajaran berlangsung sangat berperan penting untuk mencapai tujuan yang diinginkan. Dalam pembelajaran siswa memiliki kelebihan dan kekurangan masingmasing untuk menguasai materi. Ada siswa yang cepat, sedang bahkan lambat dalam menyerap pembelajaran. Biasanya tidak semua siswa menangkap apa yang di sampaikan oleh guru, karena itu guru mengharapkan partisipasi siswa untuk bertanya tentang apa yang tidak di mengertinya. Pertanyaan sangat penting dalam proses pembelajaran karena dari suatu pertanyaan guru mengetahui apa yang tidak dimengerti oleh siswa, biasanya dengan bertanya siswa akan lebih mengerti tertang apa yang telah dipelajarinya. Guru sebagai individu yang memiliki andil yang cukup besar mengusahakan segala cara agar siswa mau bertanya tentang apa yang tidak dimengertinya baik itu secara lisan maupun tulisan. Akan tetapi karena banyaknya siswa yang kurang berani, atau malu untuk 
mengeluarkan pertanyaan, maka perlu diterapkan suatu strategi yang menuntut siswa untuk bertanya melalui tulisan, untuk itu maka perlu adanya suatu inovasi dalam hal strategi pembelajaran.

Untuk mengatasi masalah diatas, maka perlu dikembangkan strategi pembelajaran yang menarik sehingga siswa tertarik mengikuti pembelajaran yang meningkatkan hasil belajar siswa. Salah satu strategi pembelajaran yang dapat digunakan untuk meningkatkan hasil belajar siswa adalah penerapan strategi pembelajaran Giving Question and Getting Answer. Strategi ini memberikan kesempatan kepada siswa untuk mengemukakan pokok pikirannya sendiri kepada teman- temannya ( menjelaskan apa yang dia pahami ) dan berdiskusi mengenai apa yang belum dimengerti dalam pembelajaran. Strategi yang didesain untuk menghidupkan suasana kelas yang menyenangkan serta melibatkan gerak fisik siswa. Keterlibatan gerak fisik ini akan meningkatkan partisipasi yang pada akhirnya meningkatkan hasil belajar siswa.

Keuntungan dari strategi ini adalah siswa berkesempatan untuk menanyakan hal-hal yang tidak dimengerti baik secara individual maupun kelompok. Guru juga dapat mengetahui sampai dimana tingkat pemahaman tentang materi yang telah disampaikan, mendorong siswa untuk menyampaikan pendapat dan menimbulkan rasa saling menghargai antar siswa. Strategi pembelajaran Giving Question and Getting Answer dikembangkan untuk melatih siswa memiliki kemampuan dan keterampilan bertanya dan menjawab pertanyaan. Pada dasarnya strategi ini merupakan modifikasi dari metode tanya jawab yang merupakan kolaborasi dengan menggunakan potongan- potongan kartu/ kertas sebagai medianya. Hal ini dilakukan agar pertanyaan siswa lebih terarah pada saat diskusi. Dengan menerapkan strategi ini, pembelajaran akuntansi siswa dapat belajar secara menyenangkan dan hasil belajar siswa diharapkan dapat meningkat.

\section{Pengertian Strategi Pembelajaran Giving Question And Getting Answers} Strategi dalam penelitian ini adalah strategi pembelajaran Giving Question and Getting Answers. Dalam strategi pembelajaran Giving Question and Getting Answers diharapkan dapat meningkatkan mutu pelajaran dikelas, sehingga hasil belajar siswa dapat ditingkatkan. Strategi pembelajaran ini dikemukakan oleh Spancer Kagan, orang berkebangsaan Swiss pada tahun 1963. Strategi ini dikembangkan untuk melatih siswa memiliki kemampuan dan keterampilan bertanya dan menjawab pertanyaan, karena pada dasarnya strategi ini merupakan modifikasi dari metode tanya jawab dan metode ceramah yang merupakan kolaborasi dengan menggunakan potongan-potongan kertas medianya. Menurut Hamruni ( 2011: 171) mengatakan " Giving Question and 
Getting Answer adalah strategi atau metode pembelajaran yang diarahkan untuk membangun tim dan melibatkan siswa dalam meninjau ulang materi pelajaran dari pelajaran sebelumnya atau diakhir pertemuan". Menurut Agus Suprijono ( 2010: 107) mengatakan Giving Question and Getting Answer dikembangkan untuk melatih siswa memiliki kemampuan dan keterampilan bertanya dan menjawab pertanyaan.

Dari pendapat diatas dapat disimpulkan bahwa strategi pembelajaran " Giving Question and Getting Answer sangat baik digunakan untuk melibatkan siswa untuk mengulang pelajaran yang telah disampaikan". Strategi ini dapat digunakan diakhir pertemuan yaitu pada 15 menit terakhir misalnya, atau diakhir semester sebagai rangkuman atau pengulangan semua materi yang telah diberikan selama satu semester.

Adapun tujuan Strategi Pembelajaran Giving Question and Getting Answer dalam suatu proses belajar mengajar adalah untuk :

1. Mengecek pemahaman siswa sebagai dasar perbaikan proses belajar mengajar.

2. Membimbing usaha para siswa untuk memperoleh suatu keterampilan kognitif maupun sosial.

3. Memberikan rasa senang pada siswa.

4. Merangsang dan meningkatkan kemampuan berfikir siswa.
5. Memotivasi siswa agar terlibat dalam interaksi

6. Melatih kemampuan mengutarakan pendapat.

7. Mencapai tujuan belajar.

Adapun prinsip- prinsip strategi pembelajaran Giving Question and Getting Answer sebagai berikut :

1. Pemberian kartu/ kertas

Dalam tekhnik pembelajaran ini, media yang digunakan adalah kartu atau kertas dengan jenis berbeda dan dibagikan kepada seluruh siswa.

2. Diskusi Kelompok

Diskusi kelompok merupakan suatu kegiatan belajar yang dapat meningkatkan hasil belajar siswa sebab adanya diskusi kelompokmemungkinkan kerja sama siswa baik dengan ataupun tanpa bimbingan guru. Suasana belajar yang menimbulkan sikap kerja sama antara siswa dalam memecahkan masalah mempunyai keuntungan yang diperoleh yaitu:

a. Dapat membina dan mengembangkan kepribadian siswa terutama sikap menghargai.

b. Pengetahuan siswa akan bertambah sebab siswa akan bertukar pikiran dengan siswa lain.

3. Presentasi

Presentasi siswa didepan kelas bertujuan untuk menguji kemampuan siswa untuk menyampaikan ide atau pendapat setelah mereka memperoleh 
pengalaman belajar. Presentasi siswa dapat meningkatkan kepercayaan diri siswa untuk tampil dan berkomunikasi didepan kelas atau diluar kelas. Siswa diajarkan agar tidak takut salah sebelum mencoba. Siswa harus menerima sanggahan atau pertanyaan dari siswa lain lain karena dalam sesi presentasi akan ada tanya jawab oleh siswa.

\section{Langkah - langkah Strategi Pembelajaran Giving Question and Getting Answer}

Adapun langkah-langkah Strategi Pembelajaran Giving Question and Getting Answer antara lain:

1. Buat potongan- potongan kartu sebanyak dua kali jumlah siswa.

2. Mintalah setiap siswa untuk melengkapi pertanyaan berikut ini:

- Kartu (1) : Saya masih belom paham tentang

○ Kartu (2) : Saya dapat menjelaskan tentang.
3. Bagi siswa kedalam kelompok kecil, 4 atau 5 orang.

4. Masing- masing kelompok memilih pertanyaan - pertanyaan yang ada kartu (1), dan juga topik- topik yang dapat mereka jelaskan kartu (2).

5. Mintalah setiap kelompok untuk membacakan pertanyaan pertanyaan yang telah mereka seleksi. Jika tidak ada diantara siswa yang bisa menjawab, guru/ dosen harus menjawab.

6. Mintalah setiap kelompok untuk menyampaikan apa yang dapat mereka jelaskan dari kartu (2). Selanjutnya mintalah mereka untuk menyampaikan ketemantemannya.

7. Lanjutkan proses ini sesuai dengan kondisi dan waktu yang ada.

8. Akhiri pembelajaran dengan menyampaikan rangkuman dan klarifikasi dari jawaban- jawaban dan penjelasan dari siswa.

Tabel 2.1

Kelebihan dan Kelemahan Strategi Giving Question and Getting Answer

\begin{tabular}{|c|c|}
\hline Kelebihan & Kelemahan \\
\hline $\begin{array}{l}\text { 1. Suasana pembelajaran menjadi } \\
\text { lebih aktif. }\end{array}$ & $\begin{array}{l}\text { 1. Pertanyaan pada hakekatnya } \\
\text { hanya hafalan. }\end{array}$ \\
\hline $\begin{array}{l}\text { 2. Siswa mendapat kesempatan } \\
\text { baik secara individu maupun } \\
\text { kelompok untuk menyampaikan } \\
\text { hal }- \text { hal yang belum } \\
\text { dimengerti. } \\
\text { 3. Guru dapat mengetahui }\end{array}$ & $\begin{array}{l}\text { 2. Guru tidak mengetahui pasti } \\
\text { apakah siswa yang tidak } \\
\text { mengajukan pertanyaan atau } \\
\text { menjawab telah memahami dan } \\
\text { telah menguasai materi yang } \\
\text { telah diberikan. }\end{array}$ \\
\hline
\end{tabular}




\begin{tabular}{|l|ll|}
\hline $\begin{array}{l}\text { penguasaan siswa terhadap } \\
\text { materi yang telah disampaikan. }\end{array}$ & 3. $\begin{array}{l}\text { Proses Tanya jawab yang } \\
\text { berlangsung secara teru - } \\
\text { menerus }\end{array}$ \\
$\begin{array}{l}\text { Mendorong siswa untuk berani } \\
\text { mengajukan pertanyaannya. }\end{array}$ & $\begin{array}{l}\text { menyimpang dari poko bahasan } \\
\text { yang sedang dipelajari. }\end{array}$ \\
\hline
\end{tabular}

Perubahan yang terjadi akibat adanya proses belajar mengajar disebut sebagai hasil belajar. Hasil belajar diartikan sebagai hasil akhir pengambilan keputusan tinggi rendahnya nilai siswa selama mengikuti proses belajar mengajar. Menurut Suprijono (2010:5) "hasil belajar adalah pola-pola perbuatan, nilai-nilai, pengertian pengertian, sikap-sikap, apresiasi dan keterampilan". Dan menurut Sudjana ( 2010: 22) "hasil belajar adalah kemampuan - kemampuan yang dimiliki siswa setelah ia menerima pengalaman belajarnya". Sedangkan menurut Winkel ( Dalam Purwanto, 2011 :45) "Hasil belajar adalah perubahan yang mengakibatkan manusia berubah dalam sikap dan tingkah lakunya". Kemudian menurut Agus Suprijono ( 2010 : 5) " Hasil belajar adalah pola-pola perbuatan, nilai-nilai, pengertian-pengertian, sikap-sikap, apresiasi dan keterampilan. Dari penjelasan diatas, dapat disimpulkan bahwa hasil belajar adalah kemampuan yang diperoleh siswa setelah kegiatan belajar yang menyebabkan perubahan dalam diri pembelajaran tersebut. Agar dapat mencapai hasil belajar yang baik, maka kita akan mengetahui hal-hal yang mempengharui hasil belajar.

\section{Pengertian Jurnal Umum}

Jurnal merupakan catatan yang dilakukan dalam proses akuntansi suatu perusahaan. Oleh karena itu, jurnal disebut book of original entry. Jurnal umum merupakan buku harian yang digunakan untuk mencatat semua jenis transaksi yang terjadi dengan mencatat semua jenis transaksi yang terjadi dengan mencatat akun yang harus dikredit beserta jumlahnya. Akun merupakan suatu catatan kenaikan saldo ( balance) dari suatu pos yang dilaporkan dalam laporan keuangan, seperti kas, persediaan, pendapatan jasa, kewajiban, modan dan beban. Dari penjelasan diatas, jurnal mempunyai beberapa fungsi:

1. Fungsi Mencatat

Jurnal merupakan alat untut mencatat semua transaksi yang terjadi secara keseluruhan berdasarkan bukti dokumen yang ada.

2. Fungsi Historis

Jurnal merupakan alat untuk mencatat semua transaksi yang terjadi sesuai dengan urutan waktunya ( kronologis )

3. Fungsi Analisis

Jurnal merupakan hasil analisis dan bukti- bukti transaksi sehingga jelas 
letak debit/ kredit dari akun yang akan dicatat beserta jumlahnya.

4. Fungsi Instruktif

Jurnal umum merupakan instruktif atau perintah untuk melakukan pemindahbukuan ( posting) kedalam buku besar.

5. Fungsi Informatif

Jurnal memberikan informasi mengenai transaksi yang terjadi sehingga kegiatan perusahaam terlihat jelas.

\section{METODE PENELITIAN}

Penelitian ini merupakan Penelitian Tindakan Kelas. Arikunto (2010: 131) mengemukakan secara garis besar terdapat empat tahapan yang dilalui dalam melaksanakan penelitian tindakan kelas yaitu: (1) perencanaan (planning) pelaksanaan (acting) (3) pengamatan (observasing) (4) refleksi (reflecting). Adapun model dan penjelasan masingmasing tahap sebagai berikut:

\section{Teknik Analisis}

Untuk mendeskrifsikan data dari variabel penelitian digunakan statistik deskriptif, yaitu mendeskrifsikan, mencatat dan menganalisa data. Setelah data didapatkan, kemudian diolah dengan teknik analisa data sebagai berikut :
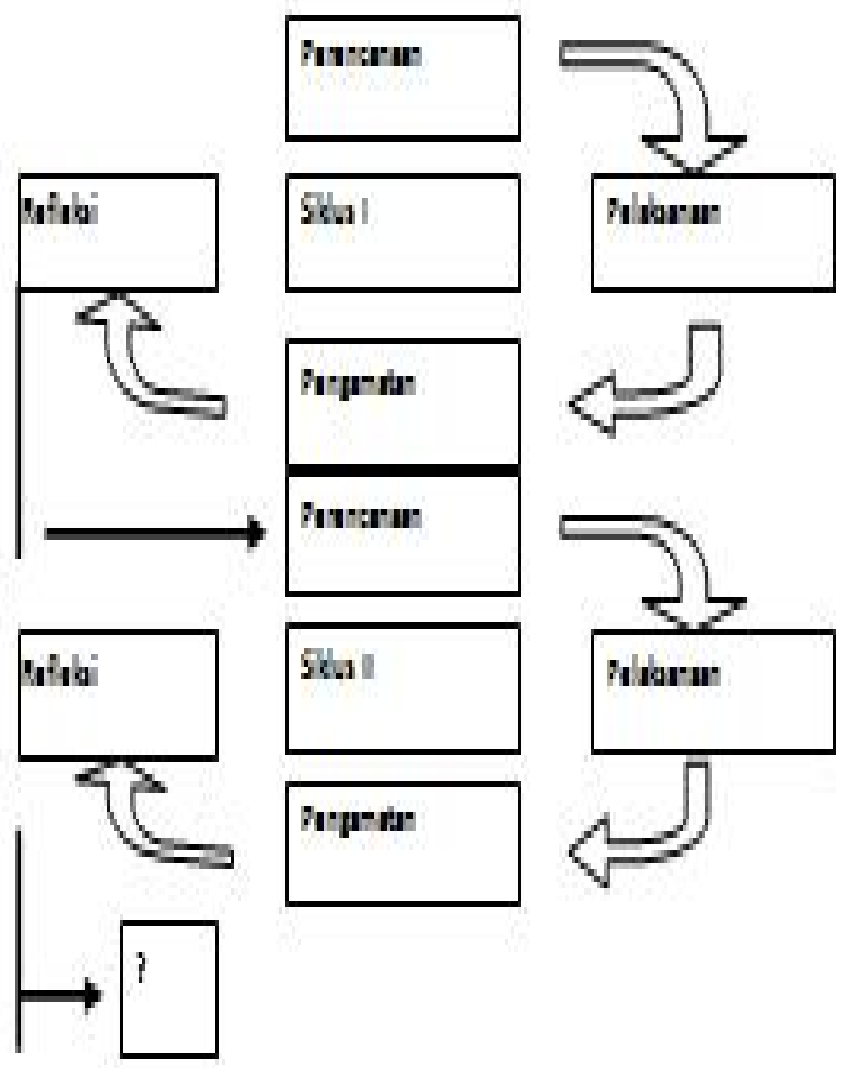

Prpethe
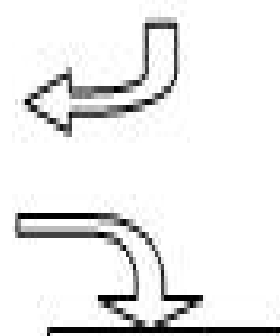

7ини"

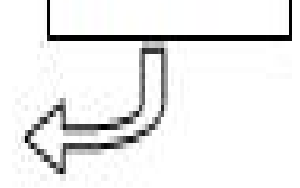



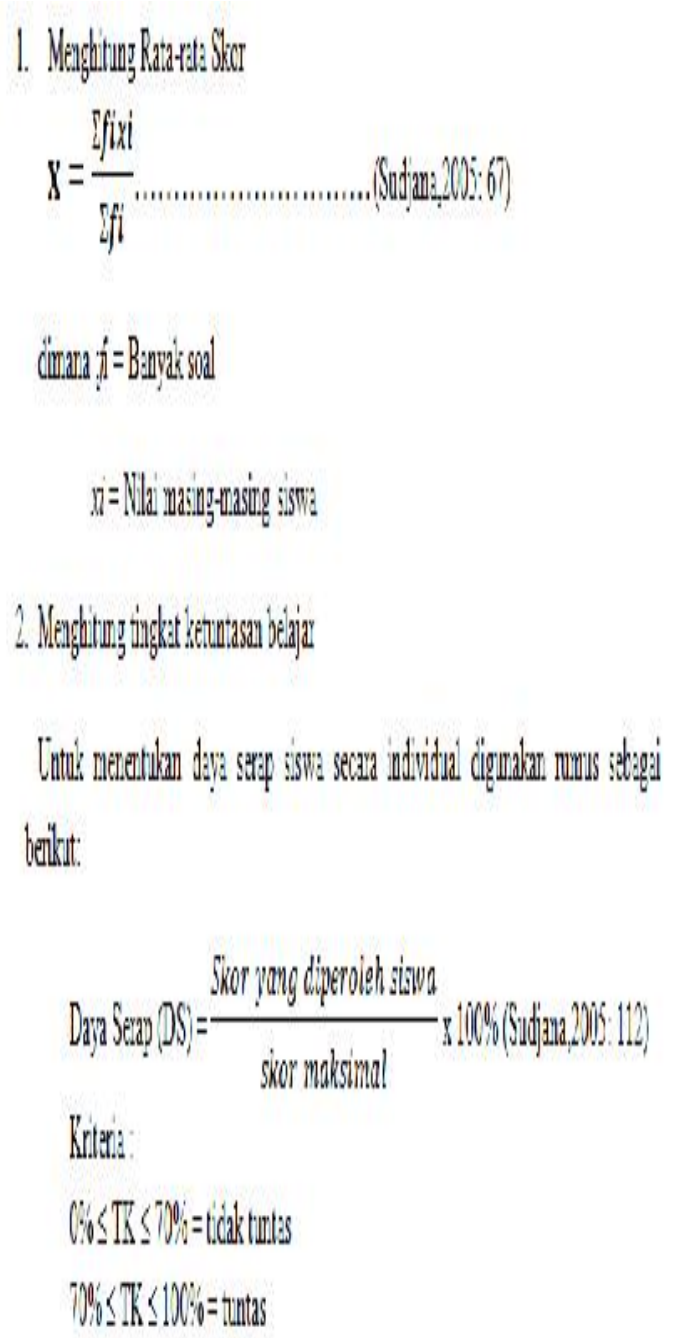

Berdasarkan kriteria ketuntasan belajar, jika kelompok secara klasikal tersebut telah mencapai $70 \%$ maka ketuntasan secara klasikal telah terpenuhi.

\section{HASIL DAN PEMBAHASAN}

Penelitian dilaksanakan didalam kelas dengan menerapkan strategi pembelajaran Giving Question and Getting Answer saat kegiatan pembelajaran berlangsung. Pada awal kegiatan penelitian diberikan siklus I untuk mengetahui sampai dimana tingkat pemahaman siswa terhadap materi yang akan dipelajari dan pada akhir pelajaran diberikan siklus II untuk mengetahui perubahan yang terjadi. Apabila hasil belajar siswa dibawah kriteria ketuntasan minimal (KKM) yaitu 75 maka siswa dinyatakan belum tuntas belajar, apabila $70 \%$ dari jumlah siswa belum mencapai nilai 75 maka ketuntasan belum terpenuhi sehingga harus dilanjutkan ke siklus selanjutnya.

Selanjutnya dapat diketahui ketuntasan belajar siswa secara klasikal dengan rumus berikut :

$\mathrm{D}=\frac{X}{N} \mathrm{X} 100 \%$ (Sudjana,2005: 115)

Dimana :

$\mathrm{D}=$ Prestasi kelas yang telah dicapai daya serapnya $\geq 70 \%$

$\mathrm{X}=$ Jumlah siswa yang telah mencapai daya serap $\geq 70 \%$

$\mathrm{N}=$ Jumlah siswa
Berdasarkan analisis data tersebut diketahui bahwa antara siklus I dan siklus II terjadi peningkatan. Sebelum dilakukan penelitian tindakan kelas jumlah siswa yang tuntas adalah 13 orang $(34,21 \%)$ dengan rata-rata 65,66 sedangkan pada saat siklus I jumlah siswa yang tuntas belajar menjadi 20 orang $(52,63 \%)$ dengan rata-rata 69,47 . Setelah data-data siklus I dianalisis maka perolehan hasil 
belajar secara klasikal menunjukkan bahwa siswa mengalami kesulitan untuk memahami materi Jurnal Umum karena skor yang diperoleh siswa tersebut tergolong rendah. Perolehan pada siklus ini belum memenuhi kriteria ketuntasan secara klasikal yaitu $70 \%$, sehingga perlu dilanjutkan ke siklus berikutnya.

Berdasarkan hasil analisis data pada siklus II dan diadakan refleksi dan evaluasi, diperoleh peningkatan hasil belajar siswa dari siklus I ke siklus II yaitu dengan jumlah siswa yang tuntas belajar pada siklus I sebesar 52,63\% meningkat menjadi $86,84 \%$ pada siklus II. Hal ini menunjukkan bahwa siklus II sudah mencapai kriteria ketuntasan secara klasikal yaitu $70 \%$.

Berikut hasil penelitian ketuntasan hasil belajar siswa dari kondisi awal peneliti sampai dengan siklus II.

Tabel 4.3 Ketuntasan Hasil Belajar Siswa

\begin{tabular}{|c|c|c|c|c|c|}
\hline \multirow{2}{*}{ Jenis Tes } & Rata- & \multicolumn{2}{|c|}{ Tuntas } & \multicolumn{2}{c|}{ Tidak Tuntas } \\
\cline { 3 - 6 } & rata & Jumlah Siswa & $\%$ & Jumlah Siswa & $\%$ \\
\hline Siklus I & 69,47 & 20 & 52,63 & 18 & 47,37 \\
\hline Siklus II & 78,42 & 33 & 86,84 & 5 & 13,16 \\
\hline
\end{tabular}

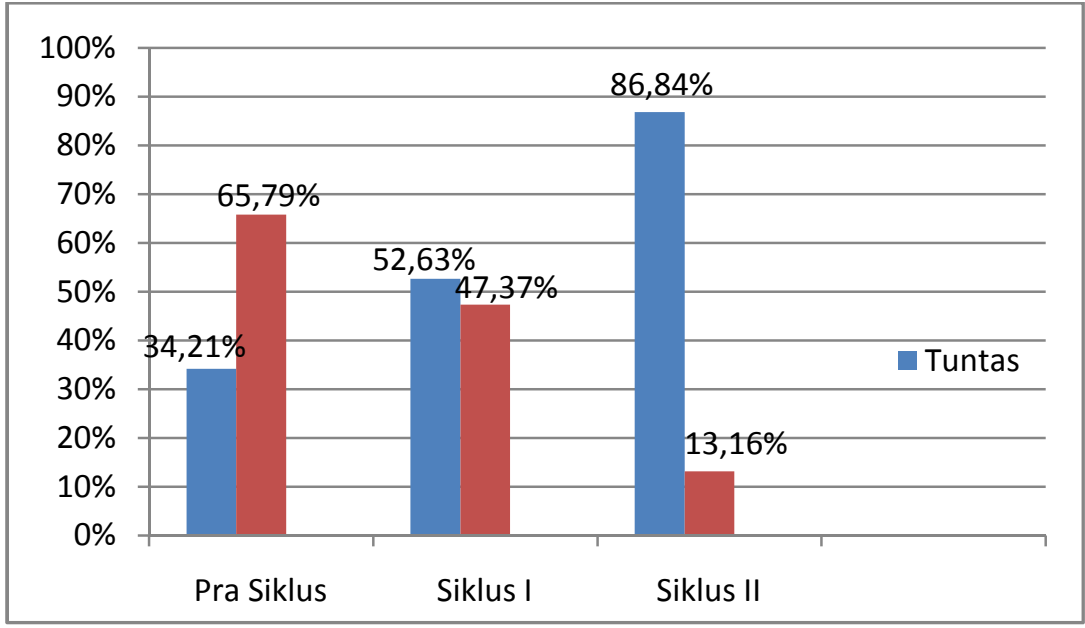

Grafik 4.3 Hasil Belajar

Berdasarkan hasil pengamatan pada siklus I diperoleh aktivitas siswa untuk diolah setelah pembelajaran selesai. Siswa yang memenuhi kriteria aktif 14 orang atau 36,84\%, cukup aktif 18 orang atau 47,37\%, kurang aktif 6 orang atau $15,79 \%$. Rekapitulasi lembar aktivitas siswa menunjukkan aspek penilaian aktivitas motorik (kecepatan dalam membahas materi) yang tergolong cukup rendah dengan jumlah 38 untuk seluruh siswa. Berdasarkan hasil observasi peneliti selama kegiatan pembelajaran berlangsung, dapat dilihat bahwa aktivitas belajar siswa masih kurang, terutama dalam membahas sub-sub pokok materi secara berkelompok 
kemudian mempersentasikannya didepan kelas. Kecendrungan siswa pasif dan hanya didominasi oleh beberapa orang saja dan hasil belajar siswa belum mencapai ketuntasan secara klasikal. Demikian juga aktivitas siswa dalam proses belajar mengajar semakin meningkat dimana 5 orang $(13,16 \%)$ siswa untuk kriteria sangat aktif, 24 orang $(63,16 \%)$ siswa untuk kriteria aktif, dan 9 orang $(23,68 \%)$ siswa untuk kriteria cukup aktif. Hal ini juga sekaligus menandakan tidak perlu dilakukan siklus selanjutnya.
Demikian juga aktivitas siswa dalam proses belajar mengajar semakin meningkat dimana 5 orang $(13,16 \%)$ siswa untuk kriteria sangat aktif, 24 orang $(63,16 \%)$ siswa untuk kriteria aktif, dan 9 orang $(23,68 \%)$ siswa untuk kriteria cukup aktif. Hal ini juga sekaligus menandakan tidak perlu dilakukan siklus selanjutnya.

Berikut adalah hasil observasi aktivitas belajar siswa dapat dilihat sebagai berikut:

Tabel 4.10

Hasil Pengamatan Aktivitas Siswa Pada Siklus I dan II

\begin{tabular}{|c|c|c|c|c|c|c|c|c|}
\hline $\mathrm{S}$ & \multicolumn{2}{|c|}{ Sangat Aktif } & \multicolumn{2}{|c|}{ Aktif } & \multicolumn{2}{|c|}{ Cukup Aktif } & \multicolumn{2}{|c|}{ Kurang Aktif } \\
\hline $\begin{array}{l}\mathrm{u} \\
\mathrm{s}\end{array}$ & $\begin{array}{c}\text { Jlh } \\
\text { Siswa }\end{array}$ & $\%$ & $\begin{array}{c}\text { Jlh } \\
\text { Siswa }\end{array}$ & $\%$ & $\begin{array}{c}\text { Jlh } \\
\text { Siswa }\end{array}$ & $\%$ & $\begin{array}{c}\text { Jlh } \\
\text { Siswa }\end{array}$ & $\%$ \\
\hline I & 0 & $0,00 \%$ & 14 & $36,84 \%$ & 18 & $47,37 \%$ & 6 & $15,79 \%$ \\
\hline II & 5 & $13,16 \%$ & 24 & $63,16 \%$ & 9 & $23,68 \%$ & 0 & 0,00 \\
\hline
\end{tabular}

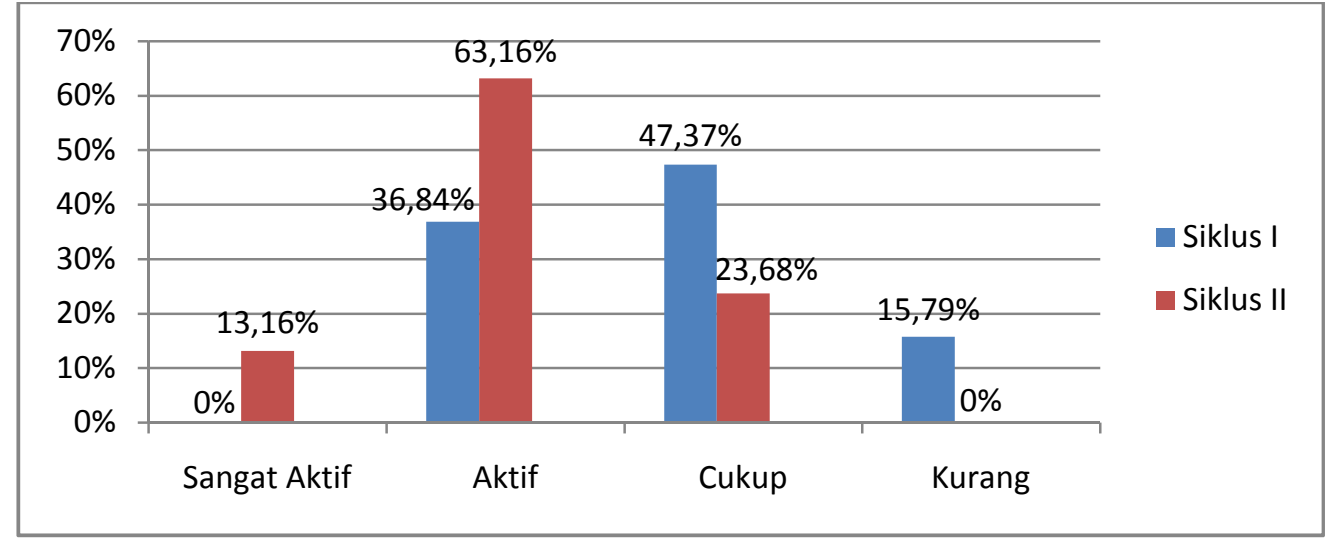

Gambar 4.4

Hasil Pengamatan Aktivitas Siswa Pada Siklus I dan II 
Peningkatan ini menunjukkan bahwa dengan menerapkan strategi pembelajaran Giving Question and Getting Answer siswa mampu memahami materi dengan baik sehingga dapat meningkatkan aktivitas dan hasil belajar siswa kelas X Akuntansi SMK Ar-Rahman Medan Tahun Pembelajaran 2016/2017.

\section{KESIMPULAN DAN SARAN}

\section{A. Kesimpulan}

1. Penerapan strategi pembelajaran Giving Question and Getting Answer mampu meningkatkan aktivitas belajar siswa yaitu pada siklus I terdapat 6 orang $(15,79 \%)$ siswa kriteria kurang aktif, 18 orang $(47,37 \%)$ siswa untuk kriteria cukup aktif dan 14 orang $(36,84 \%)$ siswa untuk kriteria aktif. Sedangkan pada siklus II mengalami peningkatan menjadi 5 orang $(13,16 \%)$ siswa untuk kriteria sangat aktif, 24 orang $(63,16 \%)$ siswa untuk kriteria aktif,dan 9 orang $(23,63 \%)$ siswa untuk kriteria cukup aktif.

2. Hasil belajar siswa setelah diterapkan strategi pembelajaran Giving Question and Getting Answer mengalami peningkatan. Peningkatan rata-rata pada siklus I 69,47 dan pada siklus II 78,42 .

\section{B. Saran}

1. Sebaiknya guru dapat menggunakan strategi pembelajaran Giving Question and Getting Answer sebagai salah satu alternative dan variasi strategi pembelajaran untuk mata pelajaran akuntansi khususnya pada materi jurnal umum dan umumnya berbagai materi yang cocok diterapkan strategi pembelajaran agar mampu meningkatkan pemahaman, motivasi belajar, aktivitas dan hasil belajar siswa.

2. Memperhatikan alokasi waktu yang digunakan pada saat pembagian kelompok didalam kelas dan sebaiknya kelompok sudah dibentuk terlebih dahulu yang sudah didiskusikan oleh guru sebelum melakukan penerapan strategi. Agar memperoleh hasil yang lebih baik diharapkan melakukan penelitian pada sekolah yang berbeda dengan objek penelitian yang berbeda pula sehingga dapat mengetahui sejauh mana strategi pembelajaran ini dapat memberi pengaruh.

\section{UCAPAN TERIMA KASIH}

Terimakasih disampaikan kepada Fakultas Keguruan dan Ilmu Pendidikan (FKIP) Universitas Muhammadiyah Sumatera Utara yang telah memberikan bantuan publikasi artikel ini. 


\section{DAFTAR PUSTAKA}

Arikunto, Suharsimi. 2013, Prosedur

Penelitian, Jakarta: PT Rineka Cipta.

Hamruni, 2011. Strategi Pembelajaran, Yogyakarta: Insan Madani.

Hisyam Zaini,dkk.2007.Strategi Pembelajaran Aktif, Yogyakarta: CTSD

Imas Kurniasih dan Berlin Sani. 2014. Teknik dan Cara Mudah Membuat Penelitian Tindakan Kelas. Jakarta: Katapena.

Margono, 2013. Metode Penelitian Pendidikan, Jakarta : Rineka Cipta.

M. Ngalim Purwanto. 2011. Prinsipprinsip dan Teknik Evaluasi Pengajaran. Bandung: Remaja Rosdakarya.

Nur'ain dkk. 2011. Belajar dan Pembelajaran, Medan: Universitas Muhammadiyah Sumatera Utara.

Purwanto, 2011. Evaluasi Hasil Belajar, Yogyakarta: Pustaka Belajar

Sardiman, 2009. Interaksi dan Motivasi Belajar Mengajar, Jakarta : PT. Raja Grafindo Persada.

Siberman, Melvin L.2014. Active Learning, Bandung: Nuansa Cendikia.

Soemarso, 2009. Akuntansi Suatu Pengantar, Jakarta : Salemba Empat.
Sudijono, Anas. 2011. Pengantar Statistik Pendidikan, Jakarta : PT. Raja Grafindo Persada.

Sudjana, Nana. 2010. Penilaian Proses Hasil Belajar Mengajar. Bandung: Rosdakrya Offset. 